\title{
Chondrocranium and internal oral morphology of the tadpole of Corythomantis greeningi (Anura: Hylidae)
}

\begin{abstract}
Marianna Isabella Rosa Rodrigues de Oliveira, ${ }^{1}$ Luiz Norberto Weber, ${ }^{2}$ Rafael O. de Sá, ${ }^{3}$ Johnny Sousa Ferreira, ${ }^{4}$ Anna Evelin Coimbra Libório, ${ }^{4}$ and André Masahide Guimarães Takazone ${ }^{4}$

${ }^{1}$ Universidade Federal da Bahia, Programa de Pós-Graduação em Diversidade Animal, Departamento de Zoologia, Instituto de Biologia, Campus Universitário de Ondina, Rua Barão de Jeremoabo, s/n, Ondina, 40170-115, Salvador, BA, Brazil. E-mail: oliveira.rmi@gmail.com.

${ }^{2}$ Universidade Federal do Sul da Bahia, Instituto Sosígenes Costa de Humanidades, Artes e Ciências, BR 367 Rodovia Porto Seguro-Eunápolis, km 10, 45810-000, Porto Seguro, BA, Brazil. E-mail: luiznorbertow@gmail.com.

${ }^{3}$ Departament of Biology, University of Richmond, Richmond, VA, 23173, USA. E-mail: rdesa@ richmond.edu.

${ }^{4}$ Universidade Federal do Maranhão, Departamento de Biologia, Centro de Ciências Biológicas e da Saúde, Avenida dos Portugueses, s/n, Campus do Bacanga, 65085-580, São Luis, Maranhão, Brazil. E-mails: annavincit@ hotmail.com, johnny. sf@gmail.com, andre_takazone@hotmail.com.
\end{abstract}

\begin{abstract}
Chondrocranium and internal oral morphology of the tadpole of Corythomantis greeningi (Anura: Hylidae). Corythomantis greeningi is a casque-headed frog that occurs in xeric and sub-humid regions of northeastern Brazil. Individuals are often found on rocks on banks of temporary streams or in ponds upon "lajedos". Suctorial tadpoles are often found clasping to the rocks in the streams so as not to be dragged by the current; therefore, they have modified external and internal morphology. Here, we describe the internal oral anatomy and the chondrocranium of the tadpole of $C$. greeningi and compare it to the available descriptions of Lophyohylinae and other suctorial tadpoles. The internal oral morphology in $C$. greeningi resembles pond-dwelling casque-headed frogs, although it has been found in temporary lotic environments. Corythomantis greeningi has unusual chondrocranial morphology relative to that of other described Lophyohylinae, including marked differences at the cornua trabeculae and palatoquadrate. Apparently, the chondrocranial morphology is related to its ecomorphology, because it is structurally more similar to other suctorial tadpoles that inhabit lotic environments than to phylogenetically related species such as Trachycephalus typhonius and Phyllodytes gyrinaethes.
\end{abstract}

Keywords: Casque-headed Frog, cranial morphology, Lophyohylinae, oral cavity.

Received 1 December 2016

Accepted 31 May 2017

Distributed June 2017 


\begin{abstract}
Resumo
Morfologia do condrocrânio e da cavidade oral do girino de Corythomantis greeningi (Anura: Hylidae). Corythomantis greeningi é uma perereca-de-cabeça-ossificada que ocorre em regiões xéricas e sub-úmidas do nordeste do Brasil. Frequentemente os indivíduos são encontrados sobre as rochas às margens de riachos temporários ou em acúmulos de água nos "lajedos". Girinos suctoriais muitas vezes são encontrados aderidos às rochas dos riachos para não serem carreados pelas correntes e por isso, apresentam morfologia externa e interna muito particulares. Aqui, descrevemos a anatomia oral interna e o condrocrânio do girino de C. greeningi e comparamos com as descrições disponíveis de representantes da subfamília Lophyohylinae e outros girinos suctoriais. A morfologia oral interna em C. greeningi assemelha-se aos girinos dos demais sapos de cabeça ossificada que se desenvolvem em poça, apesar deste ter sido encontrado em ambiente temporário lótico. Corythomantis greeningi tem uma morfologia condrocranial particular em relação aos outros Lophyohylinae descritos, apresentando marcadas diferenças nos cornua trabeculae e palatoquadrate. Aparentemente, a morfologia do condrocrânio está mais relacionada a aspectos ecomorfológicos, pois é estruturalmente mais semelhante a outros girinos suctoriais que habitam ambientes lóticos do que com espécies filogeneticamente mais próximas, como Trachycephalus typhonius and Phyllodytes gyrinaethes.
\end{abstract}

Palavras-chave: cavidade oral, Lophyohylinae, morfologia craniana, perereca-de-cabeça-ossificada.

\section{Introduction}

The neotropical genus Corythomantis Boulenger, 1896 currently comprises two species, C. galeata Pombal, Menezes, Fontes, Nunes, Rocha, and Van Sluys, 2012 and C. greeningi Boulenger, 1896. These species occur in northeastern Brazil, and the genus is currently placed in the subfamily Lophyohylinae MirandaRibeiro, 1926, along with 11 other genera. Most members of this clade are known as casqueheaded frogs: Aparasphenodon, Argenteohyla, Dryaderces, Itapotihyla, Nyctimantis, Osteocephalus, Osteopilus, Phyllodytes, Phytotriades, Tepuihyla, and Trachycephalus (Duellman et al. 2016, Frost 2017).

Corythomantis greeningi is distributed throughout Atlantic Forest and Caatinga morphoclimatic domains, in xeric and sub-humid regions of northeastern Brazil (Frost 2017). Individuals usually are found on vegetation, including in bromeliads, and frequently in rock outcrops near temporary streams (Juncá et al. 2008, IUCN 2017).

The tadpole morphology of $C$. greeningi corresponds to typical morphology for suctorial larvae inhabiting benthic fast-water habitats. According to McDiarmid and Altig (1999), suctorial tadpoles are often found clasping rocks in streams so as not to be dragged by the current and therefore have modified external and internal morphology. Juncá et al. (2008) described and illustrated the external morphology of the larvae based on specimens from Serra São José and Lages, state of Bahia, Brazil. However, the internal oral anatomy and chondrocranial morphology is not known. We describe the internal oral anatomy using scanning electron microscopy (SEM) and chondrocranial morphology of $C$. greeningi and compare them with available descriptions for other casque-headed treefrogs and suctorial tadpoles.

\section{Materials and Methods}

Tadpoles were collected at Fazenda Água Doce (12 ${ }^{\circ} 11^{\prime} 46,84^{\prime \prime}$ S, 4457'9,59" W), Municipality of Barreiras, Bahia state, Brazil. This population inhabits an area of seasonal forest in the Cerrado biome, predominant at this locality. Species identification was made by comparing the larvae with the available description in Juncá et al. 
(2008) and by raising larvae in the laboratory through metamorphosis. Voucher specimens were preserved in $8 \%$ formalin and deposited in the herpetological collection of the Museu de Zoologia da Universidade Federal da Bahia (UFBA10612) and Universidade Federal do Maranhão (HUFMA2083-2085).

Tadpole stages were determined following Gosner (1960) using Leica EZ4 and Leica 10S8APO stereomicroscopes. Morphological descriptions are based on individuals at Stage 33 and $35(N=9)$. Dissections for internal oral morphology followed Wassersug (1976). Internal oral anatomy was photographed using scanning electron microscopy (SEM). Specimens for SEM were dissected, washed for $15 \mathrm{~min}$, fixed in a 2-3\% glutaraldehyde solution for 3-4 h at room temperature, followed by three 15 min washes in $0.1 \mathrm{M}$ phosphate buffer, post fixed for $2 \mathrm{~h}$ in a $1 \%$ solution of osmium tetroxide at room temperature, and followed by another three 15 min washes in $0.1 \mathrm{M}$ phosphate buffer. Subsequently, samples were dehydrated using 15 min changes of the following graded ethanol series: $35,50,70,80,95$, and three $100 \%$ changes. Specimens were critical point dried in $\mathrm{CO}_{2}$, mounted on aluminum stubs and sputter coated with gold and palladium in camera Denton Vacuum desk III Cold sputter-Etch Unit. Features of dorsal and ventral internal oral anatomy were examined and photographed using a scanning electron microscope attached to a computer with Jeol JSM 6360LV operating system. Internal oral anatomy terminology follows Wassersug (1976). Measurements and observation of the oral morphology features were made using an ocular micrometer under a stereoscopic microscope (Leica 10S8APO).

Specimens for chondrocranial morphology were bleached and double-stained for bone and cartilage using the technique of Taylor and van Dyke (1985); terminology follows De Sá (1988) and Haas (1995, 1997). Chondrocranial illustrations were produced in Photoshop CS5 from photographs obtained under a stereomicroscope with the image analyzer.

\section{Results}

Internal Oral Morphology (Figure 1) ( $\mathrm{N}=5$, Stages 33 and 35)

The buccal floor is overall triangular; anteriorly, two pairs of infralabial papillae are present. The posterior pair is larger and handshaped with papillae along the edge. The lingual bud has one pair of lingual papillae. The buccal pockets are large and shallow, obliquely arranged, and have a few prepocket papillae and pustules. The buccal floor arena (BFA) is diamond-shaped, with 8-10 conical papillae on each side. A larger and bifurcated papilla is found on each side, closer to the buccal pocket; the buccal floor is scattered with pustulations except in the central area. The ventral velum is long, and has two marginal projections on each side of a well-marked median notch. The velar margin has secretory pits, and the glottis is distinct and exposed.

The buccal roof is overall triangular and concave. The prenarial arena bears a Y-shaped ridge and some pustulations. The nares are wide, obliquely oriented in transverse plane, and have high posterior margins forming a narial vacuites. The postnarial arena has five to six conical papillae and some pustulations. The median ridge is overall semicircular, sometimes appearing trapezoid in shape, and the free edge is slightly serrated. The lateral ridge papillae are triangular, with irregular edges. The buccal roof is densely pustulated, but lacks papillae delimiting the buccal roof arena (BRA). About three small lateral roof papillae are found aligned on each side. The glandular zone has distinct secretory pits. The dorsal velum is wide laterally and has a glandular folded edge.

Chondrocranial Morphology (Figure 2) ( $\mathrm{N}=4$, Stages 33 and 35)

The chondrocranium is oval-shaped and slightly longer than wide. The suprarostral cartilages consist of two elements: pars corporis 
and pars alaris. These elements are proximally fused at the point of articulation with the cornua trabeculae and are distally separated by a notch. The pars alaris has a short processus anterior dorsalis and a rounded and acute processus posterior dorsalis. The cornua trabeculae are robust, short, and have a broad distal edge $\mathrm{aV}$ shaped divergence and with a U-shaped notch in dorsal view; the processus lateralis trabeculae is absent.

Braincase.-The anterior wall of the braincase is formed by a broad planum ethmoidale: dorsolaterally and posteriorly it is delimited by the taenia tecti marginalis and the tectum synoticum respectively, defining a large and undivided frontoparietal fontanelle. The cartilago orbitalis is poorly chondrified (e.g. lightly stained) and the foramen opticum, $f$. trochlearis, and f. oculomotorium are not visible. Medially, the braincase floor is poorly chondrified and has a broad fenestra basicranialis; the foramen caroticum primarium and $f$. craniopalatinum are visible and ovoid-shaped.

Palatoquadrate.-This long cartilage, with smooth margins, attaches to the braincase through three connections: the commissura quadratocranialis anterior, the processus ascendens and the larval processus oticus. The processus articularis quadrati is short and wide and the commissura quadratocranialis anterior is about twice as broad as the processus articularis quadrati. The fenestra subocularis is overall ovoid, and is longer than wide. The arcus subocularis has an irregular external edge and is posteriorly narrower. The processus muscularis quadrati inclines toward the braincase; the processus quadratoethmoidalis and the commissura quadratoorbitalis are absent. The processus ascendens is short and has a low attachment to braincase.

Otooccipital region.-The otic capsules are overall quadrangular and overlie the processus ascendens; they represent about $25 \%$ of the chondrocranial length and are dorsally connected by the tectum synoticum that forms the dorsal edge of the foramen magnum. The processus anterolateralis reaches the posterior curvature of the palatoquadrate and a larval processus oticus is formed. The fenestra ovalis is moderate in size.

Lower jaws.-The cartilago Meckeli are sigmoid and articulate with the pars articularis quadrati. The cartilago infrarostrales are short, robust, and connected medially by the commissura intermandibularis.

Hyobranchial apparatus.-The copula anterior is short and the copula posterior is rectangular and has a small and truncated processus urobranchialis. The ceratohyals bear welldeveloped processus anterior hyalis, processus anterolateralis hyalis, processus lateralis hyalis, and processus posterior hyalis. The ceratohyals are joined by the pars reuniens. The condylus articularis is short. The hypobranchial plates are well-developed, medially connected by the commissura inter-hyal; ceratobranchialia $I-V$ are long, thin, and distally connected through the commissurae terminales I-III and proximally by commissura proximalis I-II; spicule I, II and III are well-developed, but spicule IV is very small and scarcely visible.

\section{Discussion}

Available information on the internal anatomy of Lophyohylinae larvae is currently limited. Among the 83 described species, the internal oral morphology has been reported in Aparasphenodon brunoi Miranda-Ribeiro, 1920 (Wogel et al. 2006), Argenteohyla siemersi (Mertens, 1937) (Cajade et al. 2010), Osteopilus ocellatus (Linnaeus, 1758) $(=$ O. brunneus Trueb and Tyle, 1974) and O. septentrionalis (Duméril and Bibron, 1841) (Lannoo et al. 1987), Osteocephalus oofhagus Jungfer and Schiesari, 1995 and $O$. taurinus Steindachner, 1862 (Schiesari et al. 1996), Phyllodytes brevirostris 


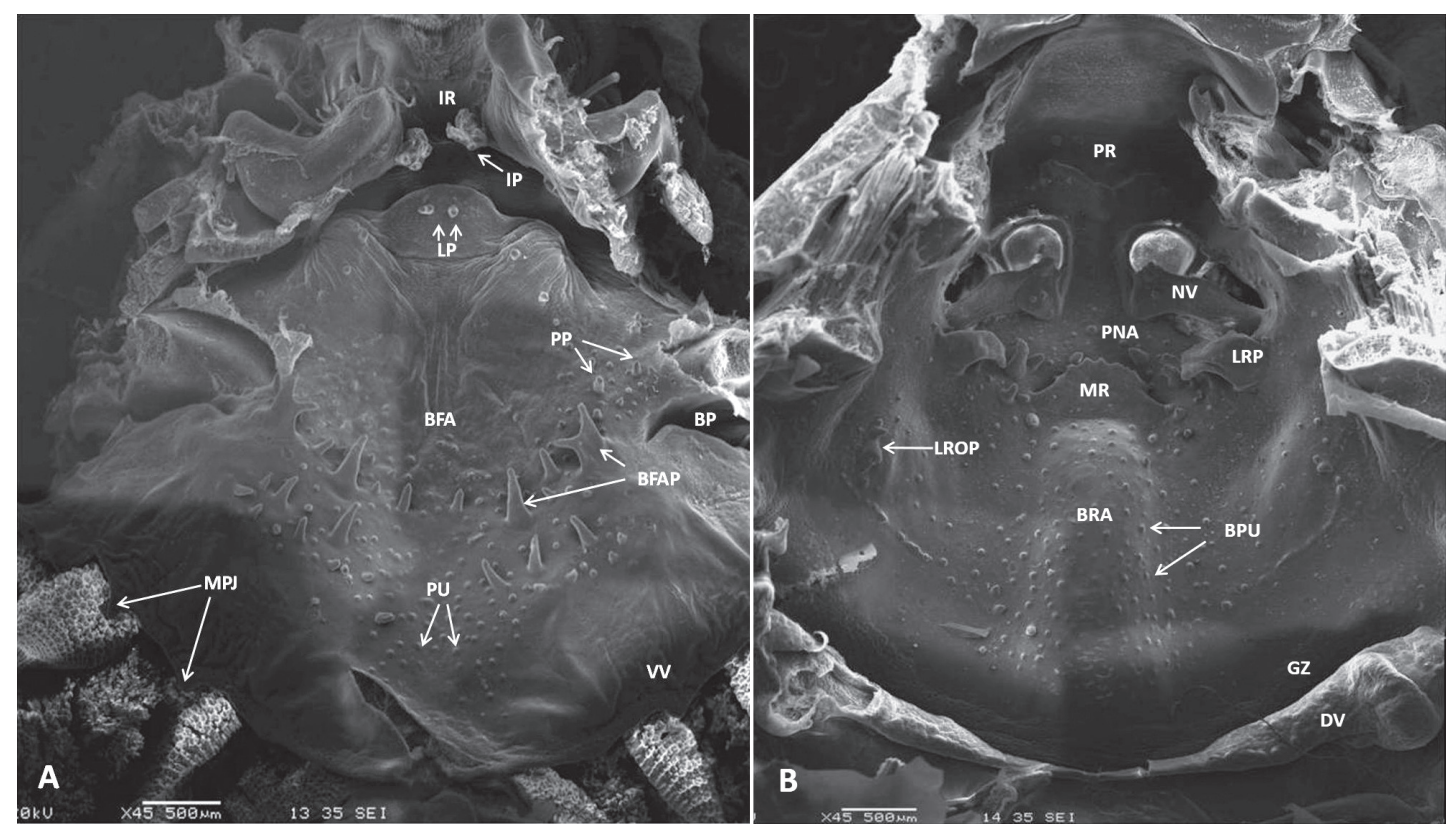

Figure 1. Internal oral morphology of Corythomantis greeningi tadpoles. (A) Buccal floor and (B) buccal roof. (IR) infralabial region, (IP) infralabial papillae, (LP) lingual papillae, (PU) pustulations, (BFA) buccal floor arena, (BFAP) buccal floor arena papillae, (PP) prepocket papillae, (BP) buccal pocket, (VV) ventral velum, (MPJ) projections and (SPT) secretory pits, (BPU) buccal roof arena pustulations, (BRA) buccal roof arena, (PR) prenarial region; (NV) narial valve, (PNA) postnarial arena, (MR) median ridge, (LR) lateral ridge, (BRA) buccal roof arena, (LROP) lateral roof papillae, (GZ) glandular zone, (DV) dorsal velum. Specimens at Stage 35.

Peixoto and Cruz, 1988 (Vieira et al. 2009), P. wuchereri (Peters, 1873) (Magalhães et al. 2015a), Trachycephalus atlas Bokermann, 1966 (Barreto et al. 2015), T. cunauaru Gordo, Toledo, Suárez, Kawashita-Ribeiro, Ávila, Morais, and Nunes, 2013 (Grillitsch 1992), T. resinifictrix (Goeldi, 1907) (Schiesari et al. 1996), and T. typhonius (Linnaeus, 1758) (Schiesari et al. 1996, Fabrezi and Vera 1997), representing only $14 \%$ of the species. Cajade et al. (2010) provided valuable comparisons of the internal oral morphology of the available Lophyohylinae tadpoles. Chondrocranial morphology has been reported only for Aparasphenodon brunoi (Da Silva 1994), Phyllodytes gyrinaethes Peixoto, Caramaschi, and Freire, 2003 (Vera-Candioti et al. 2017), T. resinifictrix (some features by Haas 2003) and T. typhonius (Fabrezi and Vera 1997).

Tadpoles of Lophyohylinae display different ecomorphological types, from the most generalized pond-dwelling species (e.g. many Trachycephalus) to those highly specialized forms such as arboreal bromeliad-dwelling types (e.g. Osteocephalus, Osteopilus and Phyllodytes), gastromyzophorous forms (e.g. P. gyrinaethes), and suctorial types such as Corythomantis greeningi (McDiarmid and Altig 1999).

Corythomantis greeningi reproduces in temporary shallow rivers, which mainly form during the rainy season across wide bare stones locally named "lagedos". In this environment, males call among rock crevices and tadpoles can be observed in small ponds along the drying 
Oliveira et al.
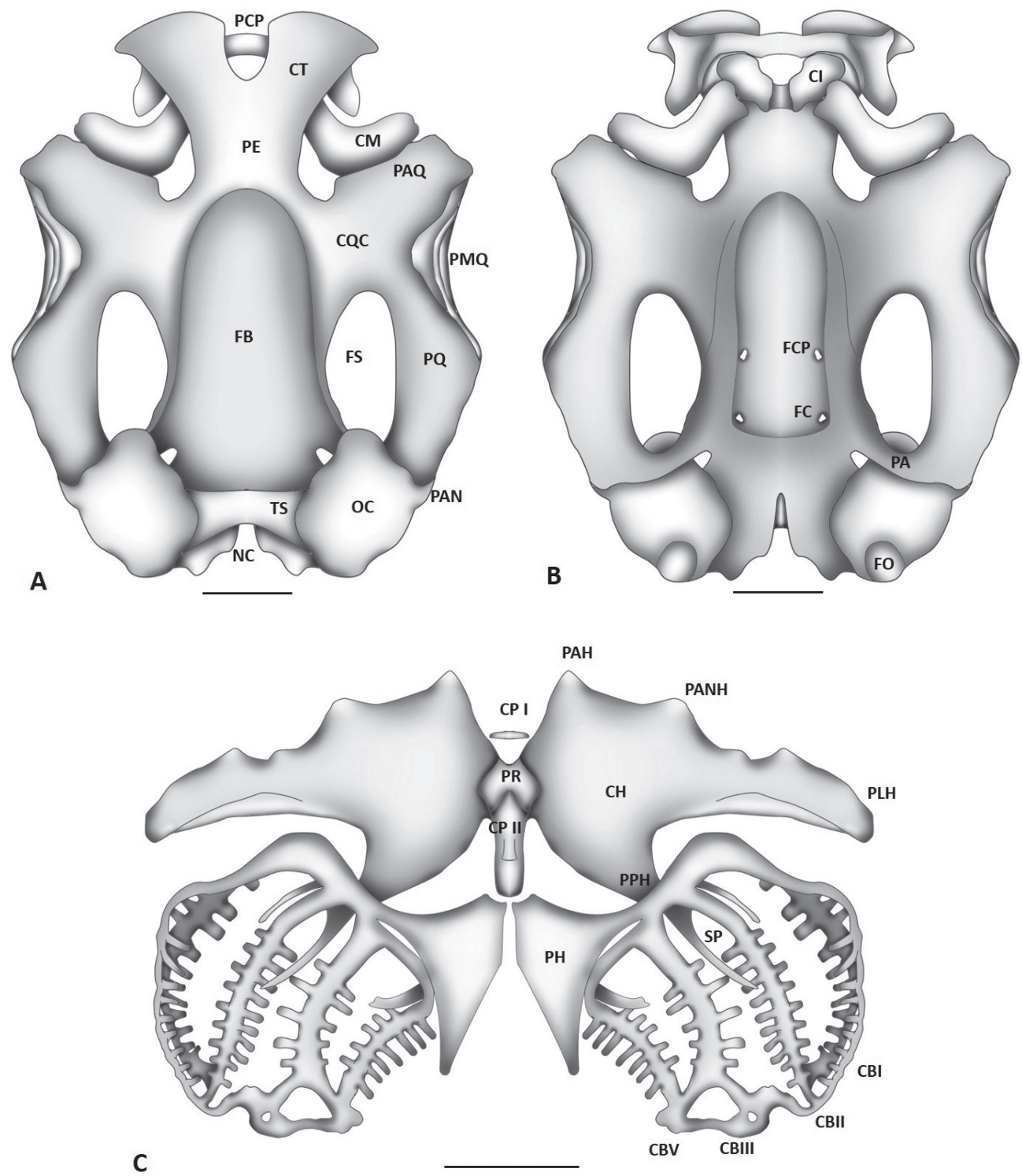

Figure 2. Chondrocranial morphology of Corythomantis greeningi tadpoles. (A) Chondrocranium in dorsal view; (B) Chondrocranium in ventral view; $(\mathbf{C})$ hyobranchial apparatus. (scale bar $=2 \mathrm{~mm})$. (Pcp) pars corporis, $(\mathrm{Cl})$ cartilagines infrarostralis, (CT) cornua trabeculae, (CM) cartilago Meckeli, (PE) planum ethmoidale, (PAQ) pars articularis quadrati, (PMQ) processus muscularis quadrati, (CQC) commissura quadratocranialis anterior, (FS) fenestra subocularis, (PQ) palatoquadrate; (PA) processus ascendens quadrati; (OC) otic capsule; (TS) tectum synoticum; (PAN) processus anterolateralis; (FB) fenestra basicranialis; (fcp) foramen craniopalatinum; (FC) foramen caroticum primarium; (NC) notochordal canal; (FO) fenestra ovalis (CPI) copula anterior, (PR) pars reuniens, (CPII) copula posterior, $(\mathrm{CH})$ ceratohyal, $(\mathrm{PAH})$ processus anterior hyalis, $(\mathrm{PANH})$ processus anterolateralis hyalis, $(\mathrm{PLH})$ processus lateralis hyalis, $(\mathrm{PPH})$ processus posterior hyalis, (PH) planum hypobranchiale, (sp) spicula, (CB I, II, III, IV) Ceratobranchial, (TS) tectum synoticum. Specimens at Stage 35. 
river bed, in lotic waters, or, frequently, clasping on the rocky river bed (Juncá et al. 2008). Suctorial anuran larvae are highly specialized for living in fast-flowing waters, using their oral discs as adhesive organs to attach to the substrate (Haas and Richards 1998).

The internal oral morphology in C. greeningi resembles pond-dwelling casque-headed frogs (Cajade et al. 2010), although it has been found in temporary lotic environments. Casque-headed frog tadpoles from lentic and lotic environments have more complex and specialized internal oral features when compared to the overall reduction observed within arboreal tree-hole-dwelling and bromeliad-dwelling casque-headed frog larvae (Cajade et al. 2010). Within the buccal floor, the infralabial region frequently has a variable number of short papillae or pustules anteriorly to one or two pairs of broad based and large papillae with branching edges. An exception is Osteopilus ocellatus ( $=$ O. brunneus), in which the infralabial region is free from papillae and pustules (Lannoo et al. 1987), and is usually associated with the first filter to select the particles that will be captured for food (Wassersug 1980).

The central area of the buccal floor arena (BFA) is always bare, with papillae and pustules found on the lateral and lower regions. The BFA papillae are often conical or digitiform; typically, there is a large papilla with a broad base or two or more fused papillae near the buccal pocket (Lannoo et al. 1987, Schiesari et al. 1996, Wogel et al. 2006, Cajade et al. 2010; this work).

The prenarial arena possess pustules or small papillae that fuse to form ridges with variable shapes (e.g. "Y", "U", "T" or irregular shaped). The choanae are wide and vary in orientation in relation to the median line (e.g., $10^{\circ}, 25^{\circ}, 45^{\circ}$, and $90^{\circ}$ ). The nasal vacuities observed in $C$. greening $i$ are unique, and not described for other Lophyohylinae species. These structures were first reported in Boana rufitela (Fouquette, 1961) (= Hyla rufitela; Wassersug 1980), suggested as chemoreceptors and considered a putative synapomorphy for the subfamily Cophomantinae, which includes the genera Aplastodiscus, Bokermannohyla, Colomascirtus, Hyloscirtus, Boana and Myersiohyla (Faivovich et al. 2005, Duellman et al. 2016). Cophomantinae and Lophyohylinae are closely related according to Duellman et al. (2016). Similar to C. greeningi, some Cophomantinae are found in lotic environments, such as temporary streams (e.g. Mongin and Carvalho-e-Silva 2013, Magalhães et al. 2015b).

Most Lophyohylinae tadpoles have densely scattered pustules on the buccal roof arena and 3-6 papillae may be found in some species (these papillae are absent in $C$. greeningi); these tadpoles commonly have short lateral roof papillae but these are variable in number among species (Lannoo et al. 1987, Schiesari et al. 1996, Wogel et al. 2006, Cajade et al. 2010; this work). Osteopilus septentrionalis lacks pustules and lateral roof papillae (Lannoo et al. 1987). Some Cophomantinae have lateral roof papillae (D 'Heursel and Haddad 2007, Mongin and Carvalho-e-Silva 2013, Magalhães et al. 2015b, Pezzuti et al. 2015).

The lack of descriptions of the chondrocranium in Lophyohylinae limits the taxonomic comparisons presented here with more closely related species. Some available descriptions are brief and do not contain illustrations. The chondrocranium of Aparasphenodon brunoi is briefly described by Da Silva (1994), but is not figured. Trachycephalus resinifictrix was not fully described by Haas (2003), and only a few characters were discussed.

Corythomantis greeningi has a different chondrocranial morphology relative to other described Lophyohylinae; marked differences occur in the cornua trabeculae and palatoquadrate. Corythomantis greeningi differs from Trachycephalus typhonius in cornua trabeculae size (larger in $C$. greeningi), shape and distal edge of the cornua trabeculae ("V" shaped and with a broad distal edge in $C$. greeningi), processus articularis quadrati and commissura quadratocranialis width (very broad in $C$. greeningi) and processus muscularis quadrati 
width (wider in C. greeningi). Corhythomantis greeningi and Trachycephalus typhonius have the parotic crista and larval processus oticus (Fabrezi and Vera 1997; this work), but these structures are absent in Phyllodytes gyrinaethes (Vera-Candioti et al. 2017).

The external and chondrocranial morphology of the tadpole of Corythomantis greeningi is more similar to other tadpoles that clasp onto substrate and inhabit lotic environments, such as Pelodryadinae Günther, 1858 Ranoidea dayi (Günther, 1897) (= Nyctimystes dayi), $R$. nannotis (Andersson, 1916) (= Litoria nannotis) and Mantellidae Laurent, 1946 Boophis sp. (Haas and Richards 1998). Tadpoles of these species are characterized by a dorsoventrally flattened body, thick tail muscle, tail fin originating posterior to the tail-body junction, undivided tooth rows, and a large, ventrally located oral disc with an uninterrupted outer row of oral papillae (Haas and Richards 1998). Some of these features are described for $C$. greeningi in Juncá et al. (2008).

According to Haas and Richards (1998) suctorial tadpoles evolved several times independently in Anura and share various features regardless of their phylogenetic position. Among these features are the cornua trabeculae that are expanded anteriorly and sometimes fused, robust lower jaws, greatest width of the skull at the level of the jaw articulation (not in $C$. greeningi), upper jaw cartilages partially or fully fused, palatoquadrate robust and connected to the skull by a wide commissura quadratocranialis anterior, processus oticus, processus basalis (in some species), and processus ascendens (vestigial or absent in some species). The external and internal morphology of the tadpole of Phyllodytes gyrinaethes recently described by Vera-Candioti et al. (2017) is highly modified, with marked restructuring of the oral region, palatoquadrate, and branchial baskets, features considered unique among known tadpoles.

The chondrocranial morphology of Corythomantis greeningi apparently is related to its ecomorphology, because it is structurally more similar to other tadpoles that inhabit lotic environments and clasp onto the substrate (e.g. Clasping, Adherent and Suctorial) (McDiarmid and Altig 1999) than to closely related species such as Trachycephalus typhonius (Fabrezi and Vera 1997) and P. gyrinaethes (Vera-Candioti et al. 2017).

The data presented in this work corroborate in part the phylogenetic tree for Lophyohylinae proposed by Duellman et al. (2016) because of the similarity between the internal oral morphology of the tadpoles of $C$. greeningi and those of pond-dwelling casque-headed frogs, such as many species of Trachycephalus. However, our data do not corroborate many aspects of the external and chondrocranial morphology, which correlates better with ecomorphology than with phylogeny.

\section{Acknowledgments}

We thank Conselho Nacional de Desenvolvimento Científico e Tecnológico (CNPq) and Fundação de Amparo a Pesquisa do Estado da Bahia (FAPESB) for financial support, Lucas Menezes (UFBA) for illustrations (www. scientificink.wix.com/scientificink) and Janalee Caldwell for the review. Specimens were collected under license number 170141, Instituto Brasileiro do Meio Ambiente e dos Recursos Renováveis-IBAMA. R.O. de Sá was supported by National Science Foundation award DEB1144692 .

\section{References}

Barreto, G. S., J. C. Ramos, E. A. Mercês, M. F. Napoli, A. A. Garda, and F. A. Juncá. 2015. External morphology and oral cavity of the tadpole of Trachycephalus atlas Bokermann, 1966 (Amphibia, Anura, Hylidae). Zootaxa 3980: 597-600.

Cajade, R., E. F. Schaefer, M. I. Duré, A. I. Kehr, and F. Marangoni. 2010. Reproductive biology of Argenteohyla siemersi pederseni Williams and Bosso, 1994 (Anura: Hylidae) in northeastern Argentina. Journal of Natural History 44: 1953-1978. 
Da Silva, H. R. 1994. Chondrocranium and cranial ossification in Aparasphenodon brunoi (Anura: Hylidae). Journal of Morphology 220: 337.

De Sá, R. O. 1988. Chondrocranium and ossification sequence of Hyla lanciformis. Journal of Morphology 195: $345-356$.

D'Heursel, A., and C. F. B. Haddad. 2007. Anatomy of the oral cavity of hylid larvae from the genera Aplastodiscus, Bokermannohyla, and Hypsiboas (Amphibia, Anura): description and systematic implications. Journal of Herpetology 41: 458-468.

Duellman, W. E., A. B. Marion, and S. B. Hedges. 2016. Phylogenetics, classification, and biogeography of the treefrogs (Amphibia: Anura: Arboranae). Zootaxa 4104: 1-109.

Fabrezi, M. and R. Vera. 1997. Caracterización morfológica de larvas de anuros del noroeste argentino. Cuadernos de Herpetología 11: 37-49.

Faivovich, J., C. F. B. Haddad, P. C. A. Garcia, D. R. Frost, J. A. Campbell, and W. C. Wheeler 2005. Systematic review of the frog family Hylidae, with special reference to Hylinae: phylogenetic analysis and taxonomic revision. Bulletin of the American Museum of Natural History 294: 1-240.

Frost, D. R. (ed.). 2017. Amphibian Species of the World: an online reference. Version 6.0. (02 April 2017). Electronic Database accessible at http://research.amnh.org/vz/ herpetology/amphibia/. American Museum of Natural History, New York, USA.

Gosner, K. L. 1960. A simplified table for staging anuran embryo and larvae with notes on identification. Herpetologica 16: 183-190.

Grillitsch, B. 1992. Notes on the tadpole of Phrynohyas resinifictrix (Goeldi, 1907). Buccopharyngeal and external morphology of a tree hole dwelling larva (Anura: Hylidae). Herpetozoa 5: 51-66.

Haas, A. 1995. Cranial features of dendrobatid larvae (Amphibia: Anura: Dendrobatidae). Journal of Morphology 224: 241-264.

Haas, A. 1997. The larval hyobranchial apparatus of discoglossid frogs: its structure and bearing on the systematics of the Anura (Amphibia: Anura). Journal of Zoological Systematics and Evolutionary Research 35: 179-197.

Haas, A. 2003. Phylogeny of frogs as inferred from primarily larval characters (Amphibia: Anura). Cladistics 19, 23 89.
Haas, A. and S. J. Richards. 1998. Correlations of cranial morphology, ecology, and evolution in Australian suctorial tadpoles of the genera Litoria and Nyctimystes (Amphibia: Anura: Hylidae: Pelodryadinae). Journal of Morphology 238:109-141.

IUCN, União Internacional para Conservação da Natureza. 2017. (02 Abr 2017). Electronic Database accessible at http: http://www.iucnredlist.org/.

Juncá, F. A., M. C. L. Carneiro, and N. N. Rodrigues. 2008. Is a dwarf population of Corythomantis greeningi Boulenger, 1896 (Anura, Hylidae) a new species? Zootaxa 1686: 48-56.

Lannoo, M. J, D. S. Towsend, and R. J. Wassersug. 1987. Larval life in leaves: arboreal tadpoles types, with special attention to the morphology, ecology and behaviour of the oophagous Osteopilus brunneus (Hylidae) larvae. Fieldiana Zoology New Serie 38:1-31.

Magalhães, F. M., F. A. Juncá, and A. A. Garda. 2015a. Tadpole and vocalisations of Phyllodytes wuchereri (Anura: Hylidae) from Bahia, Brazil. Salamandra 51: 83-90.

Magalhães, F. M., E. A. Mercês, D. J. Santana, F. A. Juncá, M. F. N. Napoli, and A. A. Garda. 2015b. The tadpole of Bokermannohyla flavopicta Leite, Pezzuti and Garcia, 2012 and oral cavity anatomy of the tadpole of B. oxente Lugli and Haddad, 2006 (Anura: Hylidae). South American Journal of Herpetology 10: 211-218.

McDiarmid, R. W. and R. Altig (eds.). 1999. Tadpoles. The Biology of Anuran Larvae. Chicago and London. The University of Chicago Press. 633 pp.

Mongin, M. M. and A. M. P. T. Carvalho-e-Silva. 2013. Descrição da morfologia oral interna, ontogenia e redescrição do girino de Bokermannohyla circumdata (Cope, 1870) (Amphibia: Anura: Hylidae). Boletim do Museu Paraense Emílio Goeldi, Ciências Naturais 8: 133-152.

Pezzuti, T. L., M. T. T.Santos, S. V. Martins, F. S. F. Leite, P. C. A. Garcia, and J. Faivovich. 2015. The tadpoles of two species of the Bokermannohyla circumdata group (Hylidae, Cophomantini). Zootaxa 4048: 151-173.

Schiesari, L. C., B. Grillitsch, and C. Vogl. 1996. Comparative morphology of phytotelmonous and ponddwelling larvae of four neotropical treefrog species (Anura, Hylidae, Osteocephalus oophagus, Osteocephalus taurinus, Phrynohyas resinifictrix, Phrynohyas venulosa). Alytes 13: 109-139.

Taylor, W. R. and G. C. van Dyke. 1985. Revised procedures for staining and clearing small fishes and other vertebrates for bone and cartilage study. Cybium 9: $107-119$. 
Oliveira et al.

Vera-Candioti, F., A. Haas, R. Altig, and O. Peixoto. 2017. Cranial anatomy of the amazing bromeliad tadpoles of Phyllodytes gyrinaethes (Hylidae: Lophyohylini), with comments about other gastromyzophorous larvae. Zoomorphology 136: 61-73.

Vieira, W. L. S., G. G. Santana, S. C. N. C. Santos, R. R. N. Alves and G. A. Pereira-Filho. 2009. Description of the tadpoles of Phyllodytes brevirostris (Anura: Hylidae). Zootaxa 2119: 66-68.

Wassersug, R. J. 1976. Oral morphology of anuran larvae: terminology and general description. Occasional Papers of the Museum of Natural History, University of Kansas 48: 1-23.
Wassersug, R. J. 1980. Internal oral features of larvae from eight families: functional, systematic, evolutionary and ecological considerations. Miscellaneous Publications of the Museum of Natural History, University of Kansas 68: $1-146$.

Wogel, H., L. N. Weber, and P. A. Abrunhosa. 2006. The tadpole of the casque-headed frog Aparasphenodon brunoi Miranda-Ribeiro (Anura: Hylidae). South American Journal of Herpetology 1: 54-60.

Editor: Vanessa K. Verdade 